\title{
Planning of Sustainable Tourism in Kosovo western region is a key factor for all involved in touristic offer
}

\author{
Merita Begolli Dauti, \\ University "Haxhi Zeka"/Kosovo \\ merita_dauti@hotmail.com
}

DOI:10.5901/mjss.2014.v5n22p235

\begin{abstract}
Tourism is one of the most complex activities in nowadays modern society. In the developed countries, as well in transition countries, is an important product of export and employment generator. It involves wide interweaving of phenomenon's and reports occurring during the touristic journey, whereas in its realization it deepens not only in the economic aspect but also in ecological, social and living culture aspect. It seems clear that the success of tourism in the realization of the role as a major moving force for the development of integrated development zone will depend on the type of structure, scale, quality, cost and location of tourist buildings. This means that the development of tourism and protection of natural and cultural heritage should be planned according to the resource base, economic and social needs and ecological sustainability. In the tourism context, planning referee widely on the expectations of the touristic activities and changes that must be done to soften the problems that negatively influence in the development through regular development promotion by effecting social, economic and environment benefits of a touristic zone and at the same time fulfilling the needs of the habitants and the tourists. Planning in tourism can be seen as a decision making and the organizing process for appointing and designing the tourism development preferred for the future. Studying the previous experiences of the touristic destinations brought to light the fact that tourism development in irregular or unplanned way will for sure lead to degradation of the bases of physical and social resource. es on what the tourism is dependent, community as well the destination. Therefore, Kosovo western destination with carefully developed plan has the possibilities to be fully successful in the aspect of achieving the high level of tourism satisfaction, positive economic benefits and minimal negative effects in the local, social and economic environment.
\end{abstract}

Key words: Planning, Tourism, Sustainability, Economy, Ecological

\section{Introduction}

The concept of stabile development even though didn't have a target in specific way the development of tourism, with no doubt had a reasonable influence in tourism department. Stabile development has an intention to secure and offer a sustainable and safe life which minimizes the use and depletion of natural resources, environmental degradation, social instability and cultural splits. (Hall 1998, p.13).

Sustainable tourism implements through managing of assets in a way to ensure integration of resources and economic development. Its long-term goal is to build a comprehensive development process that will increase the quality of local resources, motivations and understanding of market demand, the study of social-economic development, development of an option for land use, involving local people in planning decisions and management.

The sustainable tourism brings splitting of the costs and profits through touristic business, promotional and hospitable community (Godgrey 1998, p.214). In the context of tourism, planning refers broadly to expectations of tourism activities and changes that must be done to alleviate the problems that negatively affect development, through promoting the development influencing on increasing of regular social, economic and environmental profits of tourism in one area and at the same time to satisfy the needs of inhabitants and of tourists. So the destinations with diligent development planning have huge possibilities in achieving the great success in terms of achieving a high level of tourist satisfaction, positive economic profits, and minimal negative impacts on the local social, economic and physical environment. In this context one touristic destination is defined as physical space in which a visitor spends at least one night and consumes touristic products as well as support services and touristic attractions of that destination.(UNWTO, 2006).

Other authors and researchers of the touristic planning field as Baud-Bovy and Lawson identify a number of reasons why public authorities can stimulate planning in touristic field including starting and developing of tourism industry in one area 


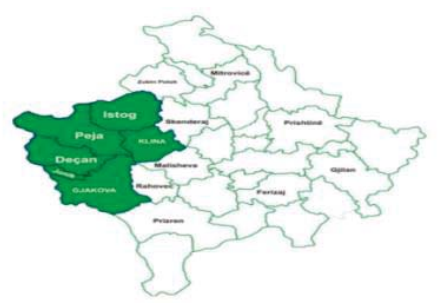

C. M. 2000). with aim to firstly evaluate possibilities for touristic development, to organize regional development of one existing resort or to protect natural resources as well as other touristic resources, to check spontaneous development by individual entrepreneurs, to protect and increase area resources and to integrate tourism development policies of the regional and economic planning.( Baud-Bovy, M. ; Lawson, F. 1971). Based to the planning tradition of tourism initially proposed by the researcher Getz and conceived further by the researcher Hall five approaches to tourism planning are considered as inalienable: economic, physical, environmental, and stable community (Hall,

The goal of sustainable development is fulfilling the need of actual tourists and visitors of the area while social and economic values are protected and maintained for the future. Development of sustainable tourism tends in managing of all resources in a manner that can fulfill economic and social needs while preserving the cultural integrity, essential ecological processes, ecologic diversity and life support systems.

\section{Grups of interest at the Touristic Destination}

As with all business in general, tourist destinations should have a variety of interested parties and groups that should be consulted at all stages of planning and decision making. The harmony of many interested parties is one of the defining characteristics of development of a sustainable tourism and to tourism in general, as well as the groups of interests can compete and cooperate (Buhalis, D. ;Cooper, C. 1998).

The groups of interest can include a range of subjects as: the government (at international, national, regional and local level); Ministries and government departments related to tourism; international organizations, national, local and regional organizations of tourism; development organizations of tourism and entrepreneurs, practitioners of tourism industry; practitioners that no business sector involves tourism, and community, including local community groups, groups of people and local residents. Groups that have a special significance for the design of a coherent and comprehensive strategy can effectively rank and three major groups of parties: governments, the tourism industry and tourist destination community. Sustainable tourism requests strategic planning of the destination, so this strategic development as well as the process of decision making should be wreathed cross-sectorial and integrated.

As we approach to the involvement of public sector support community, an involvement in Strategic Planning sustainable approach to tourism planning requires a broad range of participating groups of interest. In organizational context an actor is defined as a person or a group that can influence or be influenced by touristic activities in achieving goals and all those who have interest or believe that they have an interest to give to organization, or on the other hand can claim ownership and legal rights in activities of one corporation.( Wolf, R. A. ; Gering, D. T. 1998). Among researchers of tourism is overseen an agreement regarding the participation of the community in the process of touristic development (Tosun 2000). The community is still treated as observing object more than a partner in this process. The discussions today are not being focused at the question will the community be involved in the process of touristic development but how and when should be involved.

The main question is if involving of the community will increase the controlling of management and profits from tourist development in their areas.(Woodley, 1993). Inhabitants at the touristic destinations are heard a little or at all at the process of touristic development and as a result they can only react towards consequences at their settlements. Although touristic industry is always being criticized for decision making by the part of planning group or groups outside of the area. But if the community should be considered a legitimate group of interested parties then matters of their direct and significant participation should be right to bring a sense of ownership and the decision making. With this feeling of ownership comes also the community support for the implementation of the strategy or strategic planning.

\section{Territory and scope of the Region of Western Kosovo}

The region is located in the western part of Kosovo. It includes six municipalities as Peja, Istog, Kline, Deçan, Junik and Gjakovë with 322 settlements ( 6 cities as municipal administrative centers and villages) spread in Area of Dukagjini and in mountains around. The region is connecting point of Kosovo bordering with Albania (Gjakova and Juniku), with Montenegro (Deçani and Peja), and with Serbia (Istog Municipality). Klina Municipality borders with three other municipalities (Istog, Pejë and Gjakovë), of the region and has a position in which are located the crossroads of the main way east-west and the railway from the capital city Prishtina. Neighboring municipalities of the region in Kosova are Prizreni (J), Rahoveci and Malisheva (JL), Gllogoci and Skenderaj (VL) and Zubim Potok in northern part of the region. Sea level in large urban centers 
varies starting from $357 \mathrm{~m}$ until $520 \mathrm{~m}$, while the highest point in the region of Kosova is Gjeravica $(2,656 \mathrm{~m})$. Climatic characteristics of the Western region are almost the same as in the whole territory of Dukagjini Valley. Western Kosovo has a continental climate influenced by the Mediterranean climate. Relatively high temperatures with average annual value of $11^{\circ} \mathrm{C}$, August and July are the hottest months of the year with temperatures of $21.7^{\circ} \mathrm{C}$ and $21.68^{\circ} \mathrm{C}$ and January as the coldest month of the year with temperatures of $0.5^{\circ} \mathrm{C}$.

\section{Potential and trends of tourism}

On the basis of its geographical position, geomorphology, climate, natural and cultural resources protected by law and the other in the western region, based on the strategic location in the border triangle, potentials are summer mountain tourism, winter sports (skiing, hiking with rounds), cultural, rural, curative and rehabilitating, recreational rambler, alpine (mountains and rock climbing), flying paraglide, speleology, hunting and fishing, host, transit tourism, etc.

\begin{tabular}{|c|c|c|c|c|}
\hline Period & $\begin{array}{l}\text { Number } \\
\text { visitors(Resident) }\end{array}$ & Nights of stay & Non resident & Nights of stay \\
\hline 2008 & 19.678 & 24.616 & 22.602 & 46.910 \\
\hline 2009 & 52.631 & 36.318 & 54.876 & 76.042 \\
\hline 2010 & 44.662 & 34.382 & 45.123 & 76.394 \\
\hline 2011 & 42.044 & 30.349 & 44.757 & 65.584 \\
\hline 2012 & 49.973 & 48.790 & 52.008 & 90.968 \\
\hline
\end{tabular}

Table 1. Source: Statistics of Hotels, ASK (report 2013).These data show increasing trend of the local visitors from Kosovo for about $60 \%$ on year 2012 compared to 4 years ago (2008), even

though the increasing point was on year 2009 accompanied with a light decrease during following years, while the trend of increasing of the number of foreign tourists from 2008 to 2012 is around 50\%, while stay (sleeping nights) of local tourists and the foreing tourists increased for about the same around 50\% from 2008 to 2012 most of its changes from year to year as in the table. While, at the west region, the frequency of night stay for local and foreign tourists doubled in 2012 compared with 2008. Visually this increase is shown in the chart below according to the ASK (2013 report). .
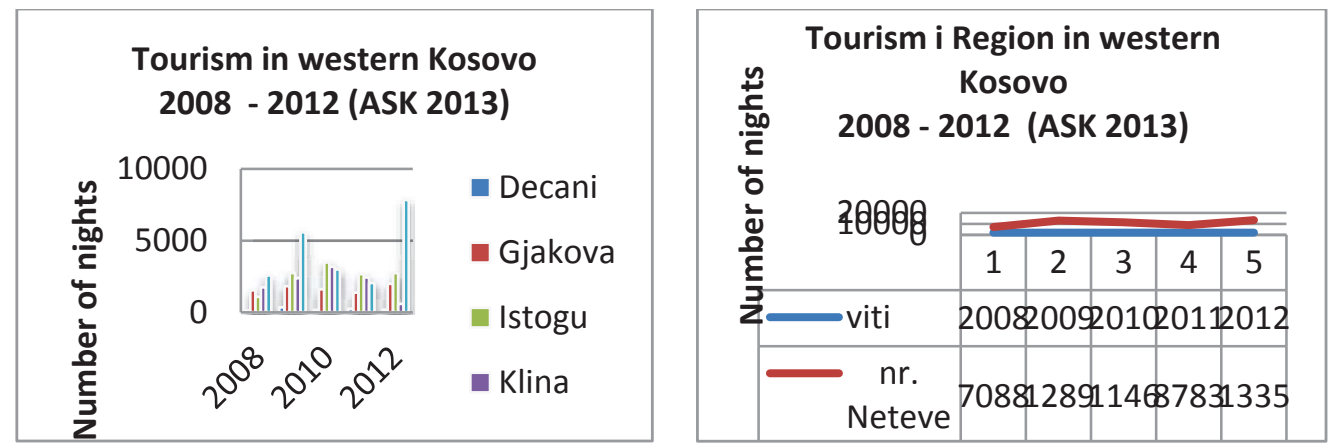

From these data we can come to the conclusion that the trend of tourism measured with nights of stay of local and foreign visitors in Western economic region is in harmony with the national ones, it means it doubled from 2008 to 2012, with increasing point on 2009, for different reasons likely declined in two following years and on 2012 reached the highest number compared to 4 past years. While on individual level Peja Municipality has the biggest increasing (triple) of nights of stay on its hotels by local and foreign visitors in western region, after her comes Istog and Gjakova. Decani has a frequency of night of stay almost uniformly while Klina faced decrease from 2010 and further. Actual and possible factors are different and should be researched for factors that could influenced in number of tourists/ nights of stay so the adequate steps could be undertaken to improve the situation

Table 2 - Hotel Capacities in Western Region.

$$
\begin{array}{l|l|l}
\text { Municipality } & \text { No of Hotels } & \text { Number of rooms }
\end{array}
$$




\begin{tabular}{|l|l|l|l|l|l|l|}
\hline & & One bed & Two beds & $\begin{array}{l}\text { Three } \\
\text { beds }\end{array}$ & Apartments & Residencies \\
\hline Deçan & 2 & 2 & 7 & 0 & 0 & 0 \\
\hline Gjakovë & 5 & 62 & 69 & 0 & 4 & 2 \\
\hline Istog & 4 & 25 & 16 & 1 & 1 & 0 \\
\hline Klinë & 4 & 21 & 26 & 6 & 3 & 0 \\
\hline Pejë & 9 & 35 & 41 & 21 & 4 & 1 \\
\hline
\end{tabular}

Based to the data that possesses the Ministry of Trade and Industry (MTI, 2013-2014) Hotel and Tourism department, as well as Statistic Agency of Kosova (SAK, 2013-2014). The cities that have most hotels surveyed are: Peja, Gjakova, Istogu, Deçani and Klina. Based on the business registers only in Peja municipality until September 2012 were existing 920 touristic operators (hotels, restaurants, cafeterias, touristic agencies). Based to the researches during the planning of developing strategy for Peja municipality (Peja Municipality 2013-2017 page.41.) only in area of Rugovo and White Drini exist this condition: 3 touristic villages, 11 motels, 2 hotels, 15 restaurants, 2 organized camping places by 2 associations. In the zone are acting 8 active households or ready to start, the others are interested to start.

Methodology of works

Methods which are being used for the project are based in available scientific literature, legal documents from touristic field and respective fields as well as surveys through questionnaires were focused in local population in five Municipalities: Peje, Gjakove, Deqane, Istog, Kline in a sample by 90 inhabitants, where 87 from them were ready to answer. Where through surveyed was attempted collection of information of peoples opinion about local touristic offer as well as their participation in the development process of their location.
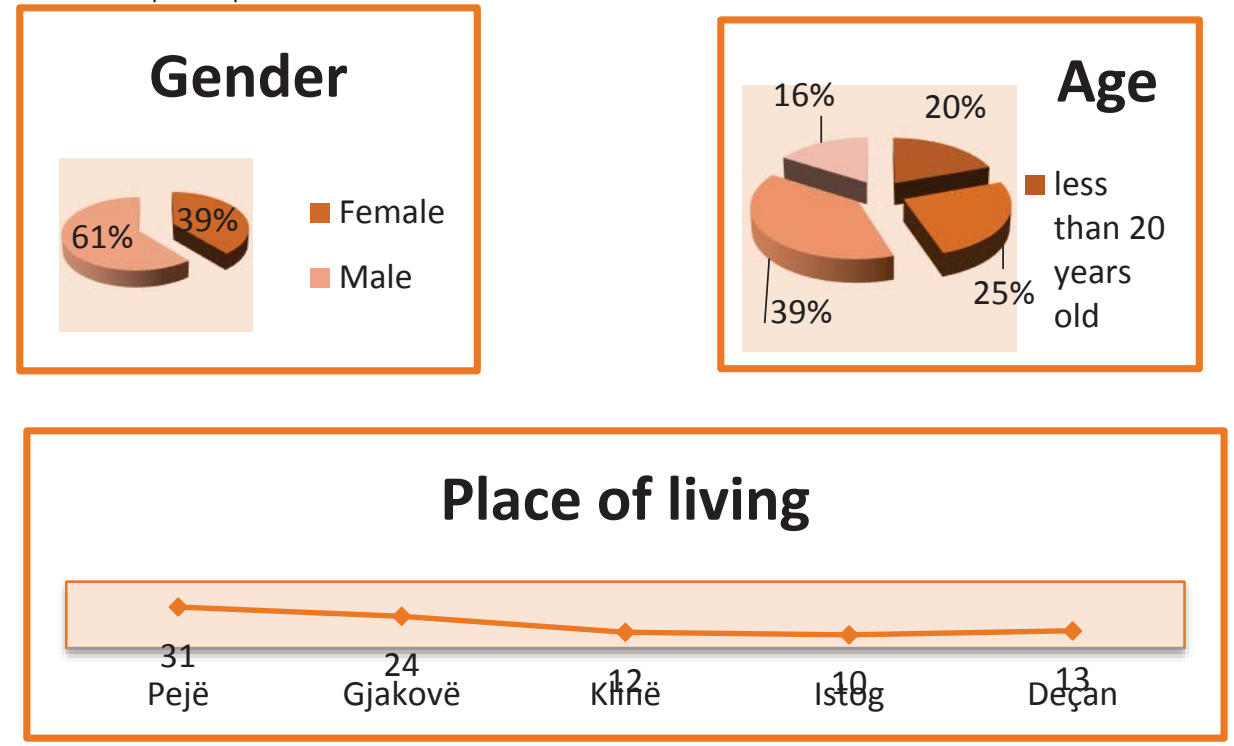

\section{How long you live in this...}

50

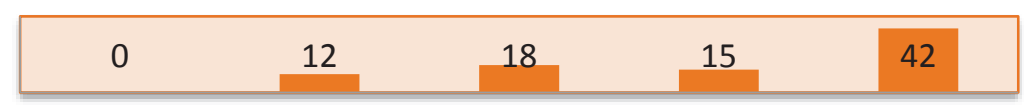

Less than 12 month $\$-5$ years $\quad 6-10$ years $11-20$ yeaßlore than 20 years 


\begin{tabular}{|c|c|}
\hline & Frequency \\
\hline \multicolumn{2}{|l|}{ What is your present occupation? } \\
\hline Agriculture & 19 \\
\hline Private bussines & 17 \\
\hline Employed in private sector & 24 \\
\hline Employed in public sector & 13 \\
\hline Unemployed & 14 \\
\hline \multicolumn{2}{|l|}{ Do you have contact with the visiting tourists? } \\
\hline Yes & 68 \\
\hline No & 19 \\
\hline \multicolumn{2}{|l|}{ What do tourists prefer to do see in these zones? } \\
\hline Visit cult objects & 26 \\
\hline To have picnics in the natural pitoresque zones & 43 \\
\hline To visit important historic objects & 18 \\
\hline \multicolumn{2}{|l|}{ Do you have any profit from tourism? } \\
\hline Yes & 82 \\
\hline No & 5 \\
\hline \multicolumn{2}{|l|}{ If Yes } \\
\hline You rent apartments & 13 \\
\hline You own a house that you rent it & 17 \\
\hline You own a hotel or restaurant /bar. & 23 \\
\hline Tourism development has positive effect in our contry economic development . & 34 \\
\hline
\end{tabular}

Please give your opinion relating the local involvement in tourism planning:

1. I do not agree at all, 2. I do not agree, 3. Neutral, 4. I agree, 5. I totally agre

Tourism planning in your zone needs local; involvement

Local involvement in tourism planning brings more profits rather than problems.

Economic profits is an important challenge for incouraging local involvement

There is a need for community awareness and education

Local habitants must be involved in the early planning process

$\begin{array}{lllll}1 & 2 & 3 & 4 & 5 \\ 2 & 5 & 7 & 29 & 44 \\ 3 & 9 & 11 & 38 & 26 \\ 0 & 6 & 4 & 31 & 46 \\ 1 & 8 & 27 & 24 & 17 \\ 7 & 4 & 17 & 19 & 40\end{array}$

Factors that effect the increase of community involvement.

1. I do not agree at all, 2. I do not agree, 3. Neutral, 4. I agree, 5. I totally agree

$\begin{array}{lllll}1 & 2 & 3 & 4 & 5 \\ 4 & 11 & 13 & 24 & 35\end{array}$

Creates new working places for the habitants 


\begin{tabular}{l|lllll}
\hline Supports the community to gain services & 7 & 14 & 11 & 28 & 27 \\
\hline Toursim chellenges the investments & 11 & 10 & 17 & 18 & 31 \\
\hline Toursim effects in saving the cultural environment & 18 & 16 & 15 & 27 & 10 \\
\hline
\end{tabular}

\begin{tabular}{l|l}
\hline \multicolumn{2}{l}{ Do you have any knowledge realting the plans and the decisions taken for tourism planning in your community? } \\
\hline Yes & 26 \\
\hline No & 61 \\
\hline If Yes how were you informed about the decisions taken from the local governance & \multicolumn{2}{l}{} \\
\hline Publication of the decions & 0 \\
\hline From the involved people in the process of decision taking & 0 \\
\hline Through TV & 52 \\
\hline Trough radio & 35 \\
\hline
\end{tabular}

How the habitants must be involved in tourism planning of the region.

\begin{tabular}{|c|c|c|c|c|c|}
\hline 1. I do not agree at all, 2. I do not agree, 3. Neutral, 4. I agree, 5. I totally agree & 1 & 2 & 3 & 4 & 5 \\
\hline To be involved in the decision making process & 11 & $\begin{array}{l}1 \\
3\end{array}$ & $\begin{array}{l}1 \\
8\end{array}$ & $\begin{array}{l}2 \\
3\end{array}$ & $\begin{array}{l}2 \\
2\end{array}$ \\
\hline To give their opinion & 9 & $\begin{array}{l}1 \\
6\end{array}$ & $\begin{array}{l}1 \\
1\end{array}$ & $\begin{array}{l}2 \\
7\end{array}$ & $\begin{array}{l}2 \\
4\end{array}$ \\
\hline To be aware of the taken decisions and to react on wrong decions & 3 & 7 & 5 & $\begin{array}{l}3 \\
0\end{array}$ & $\begin{array}{l}4 \\
2\end{array}$ \\
\hline
\end{tabular}

What advice can you give us in order to increase the local involvement in tourism planning in your community?

\begin{tabular}{|c|c|c|c|c|c|}
\hline 1. I do not agree at all, 2. I do not agree, 3. Neutral, 4. I agree, 5. I totally agree & 1 & 2 & 3 & 4 & 5 \\
\hline To make the community aware & 7 & 8 & 5 & $\begin{array}{l}3 \\
0\end{array}$ & $\begin{array}{l}3 \\
7\end{array}$ \\
\hline To conduct trainings in population active parts & 5 & 6 & $\begin{array}{l}1 \\
9\end{array}$ & $\begin{array}{l}2 \\
7\end{array}$ & $\begin{array}{l}2 \\
9\end{array}$ \\
\hline To present the problems and give them a possibility to express their opinion & 1 & 3 & $\begin{array}{l}1 \\
6\end{array}$ & $\begin{array}{l}3 \\
1\end{array}$ & $\begin{array}{l}3 \\
6\end{array}$ \\
\hline
\end{tabular}

\section{Results of questionnaire}

From the collected information was shown to us a presentation with some qualities of the community in the region. Region West which is compiled by five municipalities have a reasonable community and with specific characteristics where mainly dominates youth age. A total of 87 questionnaires, average of the responses are up to 40 years of age, while the largest percentage of respondents is $53 \%$ more males, while females its only $34 \%$. The largest number of the surveyed was from the city with biggest number of inhabitants Peja, and then follows other cities of the western region of Kosovo. Mainly 
surveyed were employed in private sector, while other were from different sectors as well as a specific number were unemployed. Most of the surveyed had contacts with tourist, visitors from foreign countries or our fellow-companions that work abroad, where mostly of these tourists $43 \%$ were having different picnics in attractive touristic areas. Most of the surveyed $82 \%$ responded positively that they benefits from tourists for the reason that a big number of them were employed in private sector and the intake of tourists affected positively in their places. As for local participation in planning of tourism most of the surveyed were positive to participate and their opinion was that they would have more economic profits. These profits would be like new job openings, inhabitants to have benefits for these services, to have new investments, to protect the environment. Most of the surveyed around 61\% didn't have knowledge regarding the plans and undertaken decisions for touristic planning in their locations also those who had knowledge with these actions $26 \%$ were notified through media (Radio, Tv). Most of the inhabitants agreed or most agreed in planning of tourism of the region, where through this commitment they will express their opinions, to get knowledge with undertaken decisions and to react towards unfair decisions.

\section{Conclusion}

Touristic values have almost all regions of Kosovo in forms and dimensions, depending from resources and the level of development. Physiognomy of the attractive elements of the western region clearly guides in the mountain regions, tourist transit directions, cities, spa and property complexes of natural and cultural heritage, hunting locations and villages. The collected information shows us a presentation with some qualities of regional community study. If we look at study areas they have a reasonable community. From the interviews done by the inhabitants emerged these problems: Inhabitants were interested for touristic development but were requesting more focusing by the local authorities as well as many critics appeared for local directors regarding the work and selection of individuals which have profits from some projects of international organizations. Afterwards inhabitants of the region saw significance in process of decision making for avoiding the problems and finding their solution. Problematic was also the departure of a big number of inhabitants especially new ages abroad to work.

\section{Recommendation}

-Cooperation between inhabitants and local authorities in the process of decision making $\mathrm{m}$ will lead in development of one destination and sustainable development of tourism.

-Accomplishment of successful cooperation between local authorities, communities and private operators in building, accomplishing of strategies, plans and programs for tourist development.

-Inhabitants of the region should have in mind their awareness in active participation in building the strategies, plans, programs of tourist development.

- Placing the new tourism products in the market and improving the quality of existing products.

- Should improve the defects that exist in the rules and laws and problems should be addressed about ownership.

-To give possibility to investors to invest in infrastructure through touristic zones.

- To protect and invest in natural, culture and archeological monuments.

- To eliminate the effect of forest degradation and to regenerate them.

- To eliminate illegal constructions.

-To place information offices in all touristic areas.

-To invest in infrastructure.

-To have a space for working places for area inhabitants.

\section{Literature:}

- Baud-Bovy, M. \& Lawson, F. 1971, Tourism and Recreation Development, The Architectural Press, London

- Buhalis, D. \& Cooper, C. 1998, 'Competition or co-operation: The needs of small and medium sized tourism enterprises at a destination level'. 
- Godgrey KB (1998) "Attitudes towards 'Sustainable Tourism' in The UK: A View from Local Government", Tourism Management, p. 213-224.

- Hall, C. M. (1998). Historical antecedents of sustainable development and ecotourism: new labels on old bottles. In C. M. Hall \& A. Lew (Eds.), Sustainable tourism. A geographical perspective (pp. 13-24). Essex, UK: Addison Wesley Longman Ltd.

- Hall, C. M. 2000, Tourism Planning: Policies, Processes and Relationships, Prentice Hall, Harlow.

- http://esk.rks-gov.net/

- https://kk.rks-gov.net

- https://kk.rks-gov.net

- kk.rks-gov.net/decan

- kk.rks-gov.net/istog

- kk.rks-gov.net/junik

- kk.rks-gov.net/peje

- Regional development strategy for the economic west region 2010-2013

- Regional Tourism Strategy for region Dukagjini \& Albanian Alps, June 2013.

- Tosun C. (2000) "Limits to Community Participation in the Tourism Development Process in Developing Countries", Tourism Management, 21, 613-633.

- Wolf, R. A. \& Gering, D. T. 1998, 'Making strategy work', The Journal of Business Strategy, vol. 19, no. 2, pp. 11-14.

- Woodley A. (1993) "Tourism and Sustainable Development: The Community Perspective" In Tourism and Sustainable Development: Monitoring, Planning, Managing. Edited by Nelson J., Butler R., and Wall G., Heritage Resources Centre, University of Waterloo.

- World Tourism Organization 2006, UNWTO News, World Tourism Organization, Madrid

- www.mti-ks.org 
